\title{
RELATIONSHIPS BETWEEN THE SEED YIELD AND SOME AGRONOMIC CHARACTERISTICS OF SAFFLOWER (Carthamus tinctorius L.) UNDER SEMI-ARID CONDITIONS
}

\author{
Zeynep SIREL $L^{1}$, Zehra AYTAC ${ }^{2 *}$ \\ ${ }^{1}$ Transitional Zone Agricultural Research Institute, Eskisehir, TURKEY \\ ${ }^{2}$ Eskisehir Osmangazi University, Faculty of Agriculture, Department of Field Crops, Eskisehir, TURKEY \\ *Corresponding author: zehrak@ogu.edu.tr
}

Received: 26.05.2015

\begin{abstract}
This study was carried out in the experimental field of Faculty of Agriculture, University of Eskişehir Osmangazi, in 2009 and 2010 under semi-arid conditions. Thirteen different safflower cultivars and lines (V49/848, V-50/166, V-50/426, V-51/263, KN 144, Finch, Sahuaripa 88, Ole, AC Stirling, Oleic Leed, US 10, N 5, UC-1) were used as materials. The cultivars and lines were planted in a Randomized Complete Block Design with three replications. Significant differences $(\mathbf{P}<0.01)$ were found for all studied yield components. The seed yield differed significantly between 976.7 and $1666.0 \mathrm{~kg} / \mathrm{ha}$. The seed yield showed a positive and significant correlation with plant height, seed yield per plant, seed weight per head and biological yield per plant. The greatest direct effect corresponded to plant height, seed weight/head and 1000-seed weight on seed yield.
\end{abstract}

Keywords: Carthamus tinctorius L., correlation coefficient, path analysis, Safflower, seed yield

\section{INTRODUCTION}

Safflower, a multipurpose crop, has been grown for centuries worldwide for the orange-red dye that is obtained from its petals, for many medicinal properties, for its feed value and especially for its high-quality oil. The plant itself is a long-season crop with a deep taproot that can draw moisture from deep in the subsoil. In addition, safflower is considered to be a moderately salttolerate crop (Maas, 1986; Mündel et al.,1992; Singh, 2007). Safflower is less selective in climatic and soil demands so it has high adaptability to low-moisture conditions. Therefore, its production worldwide is mainly confined to areas with insufficient rainfall (Arnon, 1972), it may have some production potential under low-input conditions and may have high compatibility with arid regions (Öztürk, 1994; Baydar and Gökmen, 2003).

The improvement of safflower production and its competition with other oilseed crops depends on highyielding cultivars. To increase the seed yield in safflower, it is essential to examine correlations determine the relationships between pairs of characteristics to identify suitable selection criteria for a safflower breeding program (Abel, 1976; Tabrizi, 2000; Camas et al., 2005; Alizadeh, 2005; Nabloussi et al., 2008; Kizil et al., 2008; Elfadl et al., 2010). Meanwhile, path analysis helps to determine the direct and indirect effects on seed yield and has been used to find suitable criteria for selection (Bhatt, 1973;
Tabrizi, 2000; Bidgoli et al., 2006; Ahmadzadeh et al., 2012; Hussain et al., 2014).

Interest in this crop has increased in the last few years, especially due to its production under semiarid conditions; the preference of consumers for healthy oil; the medicinal uses of flowers; and the extraction of edible dyes from flowers (Singh and Nimbkar 2007).

The objective of this research was to evaluate safflower yield components and their interrelationships in a semiarid environment and to relate the findings to improvements in safflower breeding.

\section{MATERIALS AND METHODS}

This research was carried out over two years during 2009 and 2010 at the Faculty of Agriculture of Eskisehir Osmangazi University, Eskisehir $\left(39^{\circ} 48^{\prime} \mathrm{N} ; 30^{\circ} 31^{\prime} \mathrm{E}\right.$; $789 \mathrm{~m}$ in elevation).

The field experiments included thirteen safflower (Carthamus tinctorius L.) cultivars and lines, including eight cultivars: 'Finch', 'Sahuaripa 88', 'Ole', 'AC Stirling', 'Oleic Leed', 'Us 10', 'N 5', 'UC-1'; and five lines: 'V-49/848', 'V-50/166', 'V-50/426', 'V-'51/263', 'KN 144'. All of the genotypes were obtained from the Food and Agriculture Organisation (FAO) IBPGR (International Board for Plant Genetic Resources (Table 1). The experiment was arranged in a Randomized Complete Block Design with three replications. The 
individual plots $\left(5.4 \mathrm{~m}^{2}\right)$ consisted of six rows. The plots were sown on April 13, 2009, and March 25, 2010, using a seed rate of $40 \mathrm{~kg} \mathrm{ha}^{-1}$ in $30-\mathrm{cm}$-spaced lines on a wellprepared seed bed. At planting time, phosphorus $\left(\mathrm{P}_{2} \mathrm{O}_{5}\right)$ and nitrogen $(\mathrm{N})$ were applied at a standard rate of $50 \mathrm{~kg}$ ha $^{-1} \mathrm{P}_{2} \mathrm{O}_{5}$ as di-ammonium phosphate: $18-46-0$ and $80 \mathrm{~kg}$ $\mathrm{ha}^{-1} \mathrm{~N}$ as ammonium nitrate: 33-0-0. The plants were irrigated once during emergence and thinned at the rosette stage. The weeds were controlled by hand weeding.

Table 1. Safflower genotypes

\begin{tabular}{cccc}
\hline No. & Cultivar/line & Origin & Growth Habit \\
\hline 1 & V-49/848 & Iran & Spiny \\
2 & V-50/166 & Iran & Spineless \\
3 & V-50/426 & Iran & Spiny \\
4 & V-51/263 & Iran & Spineless \\
5 & KN 144 & Iran & Spiny \\
6 & Finch & USA, Montana & Spiny \\
7 & Sahuaripa 88 & Mexico, Sonora & Spiny \\
8 & OLE & USA, Arizona & Spiny \\
9 & AC Stirling & Canada & Spiny \\
10 & Oleic Leed & USA, California & Spiny \\
11 & US 10 & USA, Maryland & Spiny \\
12 & N5 & USA, Nebrasca & Spiny \\
13 & UC-1 & USA, California & Spiny \\
\hline
\end{tabular}

The monthly rainfall, average temperatures and relative humidity data for Eskisehir in 2009 and 2010 are shown in Table 2. The long-term (1991-2010) total rainfall and average temperature were $160.1 \mathrm{~mm}$ and $15.4^{\circ} \mathrm{C}$, respectively (Table 2 ). The rainfall amount, the average temperature and the relative humidity of 2010 were higher than those of 2009. The long-term average temperature and the average temperature of the 2009 growing season were similar.

In both years, the soil of the experiment was loamy in texture and slightly alkaline, low in organic matter, moderate in $\mathrm{CaCO}_{3}$ level, low in $\mathrm{P}_{2} \mathrm{O}_{5}$, sufficient in $\mathrm{K}_{2} \mathrm{O}$ contents and had no salinity problem.

The yield components were recorded from ten randomly selected plants during both years. The biological yield per plant (BYP), plant height $(\mathrm{PH})$, number of branches per plant $(B / P)$, number of head per plant $(H / P)$, head diameter (HD), number of seeds per head $(\mathrm{S} / \mathrm{H})$, seed weight per head $(\mathrm{SW} / \mathrm{H})$, seed yield per plant (SYP), 1000-seed weight (TSW) and seed yield (SY) were evaluated both years.

The seed yield in $\mathrm{kg} \mathrm{ha}^{-1}$ was determined by harvesting the central four rows of the plot by hand. Approximately three months after harvest, as the International Seed Testing Association (ISTA) suggests, the 1000-seed weight (TSW) was calculated by counting eight replicated samples of 100 seeds from each plot and was weighed in grams.

Table 2. Meteorological data of Eskisehir*

\begin{tabular}{|c|c|c|c|c|c|c|c|c|c|}
\hline \multirow[t]{2}{*}{ Months } & \multicolumn{3}{|c|}{ Temperature $\left({ }^{\circ} \mathrm{C}\right)$} & \multicolumn{3}{|c|}{ Precipitation $(\mathbf{m m})$} & \multicolumn{3}{|c|}{ Relative humidity $(\%)$} \\
\hline & 2009 & 2010 & normal* & 2009 & 2010 & normal* & 2009 & 2010 & normal* \\
\hline March & 4.6 & 6.7 & 4.9 & 39.8 & 27.7 & 29.6 & 60.5 & 59.3 & 64.2 \\
\hline April & 10.0 & 10.2 & 9.7 & 26.0 & 41.2 & 44.3 & 55.7 & 61.2 & 62.3 \\
\hline May & 14.8 & 16.4 & 14.9 & 28.9 & 5.7 & 39,4 & 50.7 & 55.3 & 59.3 \\
\hline June & 20.4 & 19.4 & 19.2 & 7.9 & 46.6 & 24,4 & 41.0 & 59.8 & 55.0 \\
\hline July & 22.2 & 23.3 & 22.0 & 11.4 & 14.3 & 13,4 & 42.9 & 59.7 & 51.9 \\
\hline August & 21.0 & 25.3 & 22.0 & 2.0 & 1.5 & 9,0 & 42.2 & 52.0 & 53.0 \\
\hline Mean & 15.5 & 16.8 & 15.4 & & & & 48.8 & 57.8 & 58.0 \\
\hline Total & & & & 116 & 137 & 160.1 & & & \\
\hline
\end{tabular}

All of the data were calculated to an analysis of variance for each character taking level of $p<0.05$ and $\mathrm{p}<0.01$ as significant according to the LSD test using the MSTAT-C statistical program (Anonymous, 1984). In this paper, all of the characteristics are presented as an average of two years. A simple correlation analysis was carried out and the relative importance of the direct and indirect effects on the seed yield was determined by using path analysis. In the path analysis, the seed yield was the dependent variable, and the nine yield traits (mentioned above) were considered independent variables.

\section{RESULTS AND DISCUSSION}

\section{Yield and Yield components}

Significant differences $(\mathrm{P}<0.01)$ were found for all yield and yield components of thirteen safflower cultivars/lines from different origins. The year also had significant effects on all of the studied characteristics, except for 1000 -seed weight (TSW). The Cultivar $\times$ Year $(\mathrm{C} \times \mathrm{Y})$ interaction was significant for all of the characteristics except for BYP, H/P and HD (Table 3 and Table 4).

The biological yield per plant (BYP) and the plant height $(\mathrm{PH})$ varied from 13.28-22.79 $\mathrm{g}$ and 57.01-84.01 $\mathrm{cm}$, respectively. Plant height is an important characteristic that is essential under drought conditions (Alizadeh, 2005). Koutroubas et al. (2004) found a BYP between 7.85 and $13.94 \mathrm{~g}$ under Greece's ecological conditions, which was lower compared to these findings (Table 3). The US-originated cultivar 'US 10' and the Iranian lines 'V-51/263', 'V-50/426' and 'V-50/166' showed a higher $\mathrm{PH}$. The results were similar to those of 
Arslan (2007a) and Eslam et al.(2010) who found a PH from 53.4-76.7 cm under Iran's ecological conditions (Table 3).The results of the number of branches per plant
(B/P) differed between 3.7 and 7.1 and agreed with Arslan (2007a) and Camas et al. (2005) (Table 3).

Table 3. Yield components of safflower (mean values of two years)

\begin{tabular}{|c|c|c|c|c|c|}
\hline Cultivar/ lines & BYP (g) & PH (cm) & B/P (pieces) & H/P (pieces) & HD (cm) \\
\hline V-49/848 & $16,04 b-e^{+}$ & 65,29 c-e & $4,71 \mathrm{~cd}$ & $5,15 \mathrm{bc}$ & $2,39 \mathrm{a}-\mathrm{c}$ \\
\hline V-50/166 & $14,34 \mathrm{c}-\mathrm{e}$ & $70,70 \mathrm{bc}$ & 5,46 bc & $5,30 \mathrm{bc}$ & 2,28 a-e \\
\hline$V-50 / 426$ & 14,99 b-e & $70,90 \mathrm{bc}$ & $3,73 \mathrm{e}$ & $4,18 \mathrm{c}$ & $2,39 \mathrm{ab}$ \\
\hline$V-51 / 263$ & $13,28 \mathrm{e}$ & $74,03 \mathrm{~b}$ & $4,89 \mathrm{~cd}$ & $5,26 \mathrm{bc}$ & $2,50 \mathrm{a}$ \\
\hline KN 144 & $14,45 \mathrm{c}-\mathrm{e}$ & 66,12 c-e & $5,47 \mathrm{bc}$ & $5,25 \mathrm{bc}$ & $2,22 \mathrm{~b}-\mathrm{e}$ \\
\hline Finch & 18,07 a-e & 62,27 ef & 7,17 a & $6,69 \mathrm{a}$ & 2,25 a-e \\
\hline Sahuaripa 88 & 17,89 a-e & 61,94 ef & $5,95 \mathrm{~b}$ & $5,93 \mathrm{ab}$ & $2,04 \mathrm{e}$ \\
\hline OLE & $14,13 \mathrm{de}$ & $69,43 \mathrm{~b}-\mathrm{d}$ & $6,24 b$ & $5,35 \mathrm{bc}$ & $2,14 \mathrm{c}-\mathrm{e}$ \\
\hline AC Stirling & $18,61 \mathrm{a}-\mathrm{d}$ & $64,56 \mathrm{de}$ & $6,17 \mathrm{~b}$ & $6,32 \mathrm{ab}$ & $2,09 \mathrm{e}$ \\
\hline Oleic Leed & $20,18 \mathrm{ab}$ & 62,76 ef & $6,16 b$ & $6,38 \mathrm{ab}$ & $2,19 \mathrm{~b}-\mathrm{e}$ \\
\hline US 10 & $22,79 \mathrm{a}$ & $84,01 \mathrm{a}$ & $4,30 \mathrm{de}$ & $7,01 \mathrm{a}$ & 2,30 a-e \\
\hline N5 & $19,55 \mathrm{a}-\mathrm{c}$ & $69,81 \mathrm{~b}-\mathrm{d}$ & 5,32 bc & $6,22 \mathrm{ab}$ & 2,35 a-d \\
\hline UC-1 & 15,32 b-e & $57,01 \mathrm{f}$ & $4,81 \mathrm{~cd}$ & $5,92 \mathrm{ab}$ & $2,10 \mathrm{de}$ \\
\hline Average & 16,89 & 67,6 & 5,41 & 5,77 & 2,25 \\
\hline \multicolumn{6}{|l|}{ Years } \\
\hline 2009 & $17,94 \mathrm{~A}$ & $66,41 \mathrm{~B}$ & $6,17 \mathrm{~A}$ & $6,05 \mathrm{~A}$ & $2,19 \mathrm{~B}$ \\
\hline 2010 & $15,84 \mathrm{~B}$ & $68,78 \mathrm{~A}$ & $4,65 \mathrm{~B}$ & $5,48 \mathrm{~B}$ & $2,31 \mathrm{~A}$ \\
\hline Average & 16,8945 & 67,601 & 5,4125 & 5,767 & 2,2485 \\
\hline $\mathrm{C}$ & $* *$ & $* *$ & $* *$ & $* *$ & $* *$ \\
\hline $\mathrm{Y}$ & $* *$ & $* *$ & $* *$ & $* *$ & $* *$ \\
\hline $\mathrm{CxY}$ & $\mathrm{ns}$ & $* *$ & $* *$ & $\mathrm{~ns}$ & $\mathrm{~ns}$ \\
\hline
\end{tabular}

Table 4. Yield components of safflower (mean values of two years)

\begin{tabular}{|c|c|c|c|c|c|}
\hline Cultivar/lines & S/H (pieces) & SW/H(g) & SYP (g) & TSW (g) & SY (kg/ha) \\
\hline V-49/848 & $28,27 \mathrm{~cd}^{+}$ & $1,10 \mathrm{~cd}$ & $3,84 \mathrm{gh}$ & $35,17 \mathrm{de}$ & $1136,2 \mathrm{c}-\mathrm{f}$ \\
\hline V-50/166 & $31,38 \mathrm{~b}$ & $1,32 \mathrm{ab}$ & $5,03 \mathrm{c}-\mathrm{f}$ & $31,53 \mathrm{ef}$ & $1144,4 \mathrm{c}-\mathrm{f}$ \\
\hline V-50/426 & $35,81 \mathrm{a}$ & $1,42 \mathrm{a}$ & $4,29 \mathrm{f}-\mathrm{h}$ & $34,55 \mathrm{de}$ & 1123,7 d-f \\
\hline$V-51 / 263$ & $30,72 \mathrm{bc}$ & $1,14 \mathrm{~cd}$ & $4,47 \mathrm{~d}-\mathrm{g}$ & $29,60 \mathrm{f}$ & 1120,9 d-f \\
\hline KN 144 & $25,08 \mathrm{e}-\mathrm{g}$ & $1,01 \mathrm{~d}$ & $3,23 \mathrm{~h}$ & $36,22 \mathrm{~d}$ & 1059,9 ef \\
\hline Finch & $24,38 \mathrm{e}-\mathrm{g}$ & $1,19 \mathrm{bc}$ & $4,41 \mathrm{~d}-\mathrm{g}$ & $36,68 \mathrm{~cd}$ & 1062,5 ef \\
\hline Sahuaripa 88 & $22,57 \mathrm{~g}$ & $1,06 \mathrm{~cd}$ & $5,54 \mathrm{~b}-\mathrm{d}$ & $45,05 \mathrm{a}$ & $1263,2 \mathrm{~cd}$ \\
\hline OLE & $22,99 \mathrm{fg}$ & $1,15 \mathrm{~b}-\mathrm{d}$ & $4,63 \mathrm{~d}-\mathrm{g}$ & $40,23 \mathrm{bc}$ & 1083,1 ef \\
\hline AC Stirling & $24,64 \mathrm{e}-\mathrm{g}$ & $1,15 \mathrm{~b}-\mathrm{d}$ & 5,48 b-e & $42,57 \mathrm{ab}$ & $976,7 \mathrm{f}$ \\
\hline Oleic Leed & $22,21 \mathrm{~g}$ & $1,16 \mathrm{~b}-\mathrm{d}$ & $6,33 \mathrm{ab}$ & $42,40 \mathrm{ab}$ & $1312,0 \mathrm{bc}$ \\
\hline US 10 & $26,24 \mathrm{de}$ & $1,10 \mathrm{~cd}$ & $6,14 \mathrm{bc}$ & $42,13 \mathrm{ab}$ & $1666,0 \mathrm{a}$ \\
\hline N5 & $28,26 \mathrm{~cd}$ & $1,17 \mathrm{~b}-\mathrm{d}$ & $7,31 \mathrm{a}$ & $43,87 \mathrm{ab}$ & $1473,7 \mathrm{~b}$ \\
\hline UC-1 & $25,66 \mathrm{~d}-\mathrm{f}$ & $1,08 \mathrm{~cd}$ & $4,32 \mathrm{e}-\mathrm{h}$ & $42,53 \mathrm{ab}$ & 1156,6 c-e \\
\hline Average & 26,78 & 1,16 & 5,00 & 38,66 & 1198,3 \\
\hline \multicolumn{6}{|l|}{ Years } \\
\hline 2009 & $20,39 \mathrm{~B}$ & $0,86 \mathrm{~B}$ & $4,65 \mathrm{~B}$ & 39,11 & $1053,2 \mathrm{~B}$ \\
\hline 2010 & $33,17 \mathrm{~A}$ & $1,45 \mathrm{~A}$ & $5,34 \mathrm{~A}$ & 38,20 & $1343,5 \mathrm{~A}$ \\
\hline Average & 26,78 & 1,16 & 5,00 & 38,66 & 1198,4 \\
\hline $\mathrm{C}$ & $* *$ & $* *$ & $* *$ & $* *$ & $* *$ \\
\hline Y & $* *$ & $* *$ & $* *$ & ns & $* *$ \\
\hline $\mathrm{CxY}$ & $* *$ & $* *$ & $* *$ & $*$ & $* *$ \\
\hline
\end{tabular}

${ }^{+}$Values followed by different letters in a column represent significant differences;

* F-test significant at $\mathrm{P} \leq 0.05$; **, F-test significant at $\mathrm{P} \leq 0.01$; ns: non-significant, $\mathrm{C}$ (Cultivar), $\mathrm{Y}(\mathrm{Year})$

The number of head per plant $(\mathrm{H} / \mathrm{P})$, seeds per head $(\mathrm{S} / \mathrm{H})$ and seed weight per head $(\mathrm{SW} / \mathrm{H})$ are mentioned as direct components of yield (Abel, 1976). The H/P, S/H,
SW/H and HD differed between 4.18-7.01, 22.21-35.81, 1.01-1.42 $\mathrm{g}$ and 2.04-2.50 $\mathrm{cm}$, respectively. The highest $\mathrm{S} / \mathrm{H}, \mathrm{SW} / \mathrm{H}$ and HD were obtained from the Iranian lines 
(Table 3 and 4) and the results were in accordance with Alinaghizadeh et al. (2008), Omidi et al. (2012) and Sergek (2001) in similar ecological conditions. The HP values agreed with Arslan (2007a), Polat (2007) and Eslam et al. (2010).

The seed yield per plant (SYP) and the 1000-seed weight (TSW) differed between 29.60- $45.05 \mathrm{~g}$ and 3.23$7.31 \mathrm{~g}$, respectively. These results agree with Eslam et al. (2010) whereas SYP results were lower than that of Dajue and Griffee (2001) and Eren et al. (2005) (Table 4).

The seed yield (SY) differed significantly between 976.7 and $1666.0 \mathrm{~kg} / \mathrm{ha}$ and agreed with La Fuenta (1969), Alinaghizadeh et al. (2008) and Aytaç and Kınacı (2009). The highest SY was obtained from the cultivars 'US 10' and 'N5' both years. The values of SY were higher in the second year (2010) compared to the first year (2009) (1053.2 and $1343.5 \mathrm{~kg} / \mathrm{ha}$, respectively) (Table 4).The precipitation rates and the temperature values in particular between March and June in the second year during vegetative growth were higher than the first year (Table 2). This result may positively affect seed filling, which resulted in a higher seed yield, seed weight and seed number. The values for SY of the Iranian lines ' $\mathrm{V}$ 49/848', 'V-50/166', 'V-50/426', 'V-'51/263', 'KN 144' were higher in the first year compared to the second year (Figure 1). This may be occurred because of their drought resistant characteristics.

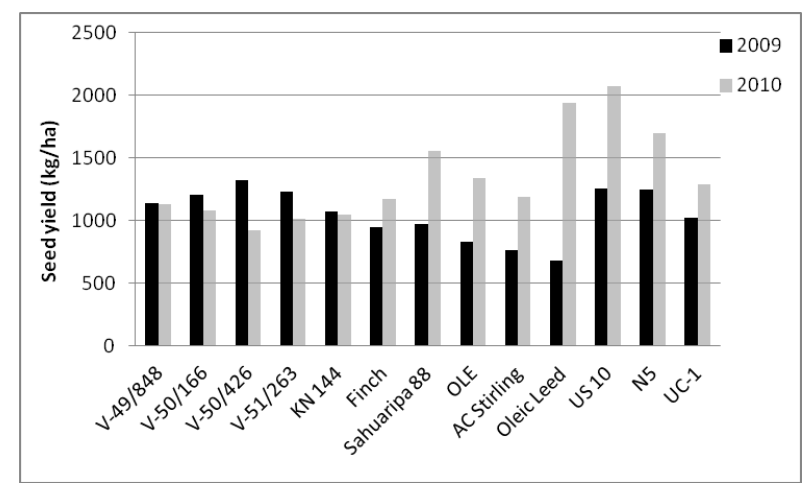

Figure 1. Seed yield of safflower (2009 and 2010)

The correlation coefficients between studied traits under semiarid conditions are presented in Table 5.

The seed yield showed a positive and significant correlation with PH (0.625), SY/P (0.532), SW/H (0.301) and BY (0.285). Some research showed a significant positive effects between SY and PH (Chaudry, 1990; Pascual-Villalobos and Alburquerque, 1995; Alizadeh, 2005; Cosge and Kaya, 2008; Aytac and Kinaci (2009). Abel (1976) found similar highly positive and significant correlations between the traits of SY with the $\mathrm{PH}$ and SW under Arizona ecological conditions. Tabrizi (2000) stated similar high correlations between the SY with the PH and SY/P under Iran's ecological conditions.

Table 5. Correlation coefficients between ten agronomic traits of safflower (mean values of two years)

\begin{tabular}{|c|c|c|c|c|c|c|c|c|c|c|}
\hline & SY & BY & PH & $\mathbf{B} / \mathbf{P}$ & $\mathbf{H} / \mathbf{P}$ & HD & $\mathbf{S} / \mathbf{H}$ & SW/H & SY/P & TSW \\
\hline SY & - & $0.285^{* *}$ & $0.625 * *$ & $-0.139 \mathrm{~ns}$ & $0.148 \mathrm{~ns}$ & $0.186 \mathrm{~ns}$ & $0.134 \mathrm{~ns}$ & $0.301 * *$ & $0.532 * *$ & $0.162 \mathrm{~ns}$ \\
\hline BY & & - & $0.150 \mathrm{~ns}$ & $0.293 * *$ & $0.733 * *$ & $-0.044 n s$ & $-0.356^{* *}$ & $-0.234 *$ & $0.421 * *$ & $0.382^{* *}$ \\
\hline PH & & & - & $-0.163 n s$ & $-0.066 n s$ & $0.333 * *$ & $0.142 \mathrm{~ns}$ & $0.160 \mathrm{~ns}$ & $0.214 \mathrm{~ns}$ & $-0.171 \mathrm{~ns}$ \\
\hline $\mathrm{B} / \mathrm{P}$ & & & & - & $0.398 * *$ & $-0.268 *$ & $-0.673 * *$ & $-0.556 * *$ & $-0.013 \mathrm{~ns}$ & $0.222 *$ \\
\hline $\mathrm{H} / \mathrm{P}$ & & & & & - & $-0.146 n s$ & $-0.387 * *$ & $-0.225^{*}$ & $0.489 * *$ & $0.307 * *$ \\
\hline HD & & & & & & - & $0.498 * *$ & $0.400 * *$ & $0.135 \mathrm{~ns}$ & $-0.417 * *$ \\
\hline $\mathrm{S} / \mathrm{H}$ & & & & & & & - & $0.854 * *$ & $0.142 \mathrm{~ns}$ & $-0.359 * *$ \\
\hline $\mathrm{SW} / \mathrm{H}$ & & & & & & & & - & $0.394 * *$ & $-0.203 \mathrm{~ns}$ \\
\hline SY/P & & & & & & & & & - & $0.307 * *$ \\
\hline TSW & & & & & & & & & & - \\
\hline
\end{tabular}

The biological yield showed a positive and significant correlation with H/P (0.733), SY/P (0.421), TSW (0.382) and B/P (0.293). Tabrizi (2000) found similar high correlations between the BY and the SY/P and TSW under Iran's ecological conditions

The seed yield per plant was positively and significantly correlated with the SY (0.532), H/P (0.489), BY (0.421), SW/H (0.394) and TSW (0.307). Tabrizi (2000) and Nabloussi et al. (2008) found positive and significant correlations between the TSW, 100-seed weight and the SY/P.

Plant height was positively and significantly correlated with the SY (0.625) and HD (0.333) whereas the relationships between the recent traits were nonsignificant.
Arslan (2007b), Cosge and Kaya (2008) and Hussain et al. (2014) found similar high correlation between the PH and SY. Alizadeh (2005) and Ahmadzadeh (2012) reported the importance of increasing plant height on the seed yield of safflower in dryland of Iran.

The seed weight/head was positively and significantly correlated with the S/H (0.854), HD (0.400), SY/P (0.394) and SY (0.301). Similarly, Bidgoli et al. (2006) found highly positive correlations among the SW/H with SY and $\mathrm{SH}$.

The number of branches/plant showed a positive and significant correlation with the H/P (0.398) and TSW (0.222). Tabrizi (2000), Arslan (2007b) and Aytac and Kinaci (2009) found similar high correlations between the 
$\mathrm{B} / \mathrm{P}, \mathrm{C} / \mathrm{P}$ and TSW. The number of head/plant was positively and significantly correlated with the SY/P (0.489) and TSW (0.307). Abel (1976), Tabrizi (2000) and Pascual-Villalobos and Alburquerque (1996) reported significant high correlations between the $\mathrm{H} / \mathrm{P}$, the seed yield and 100-seed weight. Significant negative correlations were found between the $\mathrm{H} / \mathrm{P}$ and the S/H (0.387) which was in accordance with Alizadeh (2005). The head diameter was positively and significantly correlated with the S/H (0.498) and SW/H (0.400). Abel (1976), Bidgoli et al. (2006), Kizil et al. (2008) and Hussain et al. (2014) found similar highly positive correlations between the HD and S/H.

The number of seeds/head was positively and significantly correlated with the SW/H (0.854) and HD (0.498). Similarly, Bidgoli et al. (2006) found highly positive correlations between the S/C and SW/H. Significant negative correlations were found between the S/C and TSW (-0.359). Alizadeh (2005) and PascualVillalobos and Alburquerque (1996) also reported negative correlations between the number of seeds and the hundred-seed weight. This may be because of the negative relationship between the seed number and 1000-seed weight depended on genotype and ecological conditions. The increase of the seed number does not always increases the seed weight (Kolsaric1 et al., 1993).

\section{Path analysis}

The path coefficient analysis revealed that the seed yield of safflower depended on the positive direct effects of PH (\%75.4), SYP (\%43.7), SW/H (\%37.9), TSW (\%30.7) and BY (\%12.6) (Table 6). On the other hand it depended on negative direct effects of $\mathrm{S} / \mathrm{H}, \mathrm{B} / \mathrm{P}, \mathrm{C} / \mathrm{P}$ and HD. These results agree with the report of Bidgoli et al. (2006) who indicated strong direct effects of biomass, SW/H and TSW and negative direct effect of the HD on the seed yield. Ahmadzadeh et al. (2012) found positive direct effects of hundred seed weight on the seed yield in both irrigated and drought conditions while plant height had a direct effect on the seed yield in irrigated conditions. Golparvar (2011) and Behnam et al. (2011) reported also positive direct effects of TSW on the seed yield in both normal and stressed conditions. Many research indicated positive direct effects of seeds per head on the seed yield while the $\mathrm{S} / \mathrm{H}$ had a negative direct effect on the seed yield in this study. This may be because of the various ecological conditions and genotypes (Behnam et al., 2011; Ahmadzadeh et al., 2012; Golkar et al., 2011; Arslan, 2007a) and the increase of the seed number does not always increases the seed weight (Kolsarıc1 et al., 1993) and directly the seed yield.

Table 6. Path coefficients for seed yield components of safflower (mean values of two years)

\begin{tabular}{|c|c|c|c|c|c|c|c|c|c|c|}
\hline \multirow{2}{*}{ Trait } & \multicolumn{10}{|c|}{ Indirect effect via } \\
\hline & BY & PH & B/P & H/P & HD & $\mathbf{S} / \mathbf{H}$ & SW/H & SY/P & TSW & Overall Effect \\
\hline \multirow{2}{*}{ BY } & $\underline{0.0648}$ & 0.0835 & $\begin{array}{l}-0.0191 \\
\end{array}$ & -0.0239 & 0.0001 & 0.0703 & -0.0654 & 0.1143 & 0.0604 & \multirow{2}{*}{$0.285 * *$} \\
\hline & $\overline{\% 12.6}$ & $\% 16.6$ & $\% 3.8$ & $\% 4.7$ & $\% 0.02$ & $\% 14.0$ & $\% 13.0$ & $\% 22.7$ & $\% 12.0$ & \\
\hline \multirow{2}{*}{ PH } & 0.0097 & $\underline{0.5557}$ & 0.0106 & 0.0021 & -0.0006 & -0.0282 & 0.0445 & 0.0581 & -0.0270 & \multirow{2}{*}{$0.625^{* *}$} \\
\hline & $\% 1.3$ & $\% 75.4$ & $\% 1.4$ & $\% 0.3$ & $\% 0.1$ & $\% 3.8$ & $\% 6.0$ & $\% 7.8$ & $\% 3.7$ & \\
\hline \multirow{2}{*}{$\mathrm{B} / \mathrm{P}$} & 0.0190 & -0.0905 & $\underline{-0.0651}$ & -0.0130 & 0.0005 & 0.1331 & -0.1551 & -0.0035 & 0.0351 & \multirow{2}{*}{$-0.139 \mathrm{~ns}$} \\
\hline & $\% 3.7$ & $\% 17.6$ & $\% 12.6$ & $\% 2.5$ & $\% 0.1$ & $\% 25.8$ & $\% 30.1$ & $\% 0.7$ & $\% 6.8$ & \\
\hline \multirow{2}{*}{$\mathrm{H} / \mathrm{P}$} & 0.0475 & -0.0366 & -0.0259 & $\underline{-0.0325}$ & 0.0003 & 0.0765 & -0.0627 & 0.1329 & 0.0485 & \multirow{2}{*}{$0.148 \mathrm{~ns}$} \\
\hline & $\% 10.2$ & $\% 7.8$ & $\% 5.6$ & $\overline{\% 7.0}$ & $\% 0.1$ & $\% 16.5$ & $\% 13.5$ & $\% 28.7$ & $\% 10.5$ & \\
\hline \multirow{2}{*}{ HD } & -0.0028 & 0.1849 & 0.0175 & 0.0048 & $\underline{-0.0019}$ & -0.0984 & 0.1115 & 0.0366 & -0.0660 & \multirow{2}{*}{$0.186 \mathrm{~ns}$} \\
\hline & $\% 0,5$ & $\% 35.3$ & $\% 3.3$ & $\% 0.9$ & $\% 0.3$ & $\% 18.8$ & $\% 21.3$ & $\% 6.9$ & $\% 12.6$ & \\
\hline \multirow{2}{*}{$\mathrm{S} / \mathrm{H}$} & -0.0230 & 0.0792 & 0.0438 & 0.0126 & -0.0009 & $\underline{-0.1977}$ & 0.2382 & 0.0387 & -0.0568 & \multirow{2}{*}{$0.134 \mathrm{~ns}$} \\
\hline & $\% 3.3$ & $\% 11.4$ & $\% 6.3$ & $\% 1.8$ & $\% 0.1$ & $\% 28.6$ & $\% 34.5$ & $\% 5.6$ & $\% 8.2$ & \\
\hline \multirow{2}{*}{$\mathrm{SW} / \mathrm{H}$} & -0.0152 & 0.0887 & 0.0362 & 0.0073 & -0.0008 & -0.1688 & $\underline{0.2791}$ & 0.1068 & -0.0321 & \multirow{2}{*}{$0.301 * *$} \\
\hline & $\% 2.06$ & $\% 12.06$ & $\% 4.91$ & $\% 0.99$ & $\% 0.10$ & $\% 22.96$ & $\overline{\% 37.9}$ & $\% 14.5$ & $\% 4.4$ & \\
\hline \multirow{2}{*}{ SY/P } & 0.0273 & 0.1189 & 0.0009 & -0.0159 & -0.0003 & -0.0282 & 0.1098 & $\underline{0.2715}$ & 0.0485 & \multirow{2}{*}{$0.532 * *$} \\
\hline & $\% 4.4$ & $\% 19.1$ & $\% 0.1$ & $\% 2.6$ & $\% 0.1$ & $\% 4.5$ & $\% 17.7$ & $\% 43.7$ & $\% 7.8$ & \\
\hline \multirow{2}{*}{ TSW } & 0.0247 & -0.0951 & -0.0145 & -0.0100 & 0.0008 & 0.0711 & -0.0568 & 0.0834 & $\underline{0.1580}$ & \multirow{2}{*}{$0.162 \mathrm{~ns}$} \\
\hline & $\% 4.1$ & $\% 18.5$ & $\% 2.8$ & $\% 1.9$ & $\% 0.2$ & $\% 13.8$ & $\% 11.0$ & $\% 16.2$ & $\% 30.7$ & \\
\hline
\end{tabular}

The diagonal under line numbers is direct effects of any trait on seed yield

The seed yield per plant and biological yield showed positive direct effects on the seed yield as it mentioned above. The SY/P depended on the positive indirect effects of PH (\%19.1), SW/H (\%17.7), TSW (\%7.8), BY (\%4.4) and $\mathrm{B} / \mathrm{P}(\% 0.1)$ while these traits had direct effects on SY. The BY depended on the positive indirect effects of SY/P (\%22.7), PH (\%16.6), S/H (\%14.0), TSW (\%12.0) and HD (\%0.02) while the other traits had negative indirect effects (Table 6).
Plant height showed a positive direct effect (\%75.4) on the seed yield under semiarid conditions. Plant height had a positive indirect effect on the SY/P (\%7.8), SW/H (\%6.0), B/P (\%1.4), BY (\%1.3) and H/P (\%0.3), while the other traits had negative indirect effects. The indirect effects via plant height and SY/P, SW/H, BY and H/P substantially increased the total correlation between the traits and seed yield except for HD, S/H and TSW (Table 6). Topal (2010), Hussain et al. (2014) and Bahmankar et al. (2014) stated also high positive direct effect and high 
genetic advance coupled with heritability of plant height on the seed yield.

The seed weight/head had a positive direct effect (\%37.9) on the seed yield under semiarid conditions. The SW/H had a positive indirect effect on the SY/P (\%14.5), $\mathrm{PH}(\% 12.0), \mathrm{B} / \mathrm{P}(\% 4.9)$ and H/P (\%0.9) while the other traits had negative indirect effects (Table 6). Patil et al. (1990) reported that the direct effect of the H/P and the indirect effect of the seed weight/plant on the seed yield were the greatest. Bidgoli et al. (2006) reported also a strong direct effect of the SW/H on the seed yield and a strong indirect effect of the biomass on the SW/H.

The 1000-seed weight showed a positive direct effect (\%30.7) on the seed yield and had a positive indirect effect on SY/P (\%16.2), S/C (\%13.8), BY (\%4.1), CD $(\% 0.2)$ while the other traits had negative indirect effects (Table 6). Bidgoli et al. (2006) reported a positive indirect effect of biomass on the TSW. Hussain et al. (2014) and Karimi et al. (2013) stated that 1000-seed weight and plant height had the highest direct effect on seed yield and reported that these traits had genetical potential to introduce as the best indirect selection criteria to improve seed yield in safflower cultivars.

The results of the correlation and path analysis in this study revealed similar results for interrelationships among several traits. The seed yield had significant and positive correlation coefficients with plant height, seed yield per plant, seed weight per head and biological yield. The highest direct effects on the seed yield corresponded to plant height, seed yield per plant, seed weight per head, 1000 -seed weight and biological yield. The seed yield per plant and biological yield showed positive direct effects on the seed yield. Both traits depended on the higher positive indirect effects of plant height, seed weight per head and 1000-seed weight.

Highly significant and positive correlation coefficients as well as high direct effects of plant height, seed weight per head, 1000-seed weight on the seed yield indicated that these components could be the most important yield contributing characters among the yield traits for selecting high yielding genotypes in semiarid conditions. The plant height, seed weight per head and the 1000-seed weight had the highest direct effects on the seed yield. These traits have genetic potential to introduce as the best indirect selection criteria to improve the seed yield in safflower.

\section{LITERATURE CITED}

Abel, G.H.1976. Relationship and use of yield components in safflower breeding. Agron. J. 68: 442-447.

Ahmadzadeh, A.R., B.Alizadeh, H.A.Shahryar and M. Narimani. 2012. Path analysis of the relationships between grain yield and some morphological characters in spring safflower (Carthamus tinctorius) under normal irrigation and drought stress condition. J. Medi. Plants Res. 6(7): 1268-1271.

Alinaghizadeh, M., M. Dehnavi, H. Faraji, A. Dehdari and M. Gandomani. 2008. Effects of sowing dates on yield components of different spring safflower (Carthamus tinctorius) cultivars as a douple crop in Yasouj. Iran. 7th International Safflower Conference, Australia.

Alizadeh, K. 2005. Evaluation of safflower germplasm by some agronomic characteristics and their relationships on grain yield production in the cold dry land of Iran. International Journal of Agriculture \& Biology. 7(3): 389-391.

Anonymous, 1984. MSTAT-C Microcomputer statistical program. Michigan State University. East Lansing, MI, USA.

Arnon, I. 1972. Crop production in dry regions .Vol. 2, pp. 1119. Leonard Hill, London.

Arslan, B. 2007a. The path analysis of yield and its components in safflower (Carthamus tinctorius L.). Journal of Biological Sciences. 7(4): 668-672.

Arslan, B. 2007b. Assessing of herbitability and variance components of yield and some agronomic traits of different safflower (Carthamus tinctorius L.) cultivars. Asian Journal of Plant Sciences. 6(3): 554-557.

Aytaç, Z. and G. Kınacı 2009. Variability, heritability and relationships between seed yield and some characters of safflower genotypes. 8. Field Crops Congress, 19-22 Ekim 2009, Hatay, Turkey.

Bahmankar, M., M.R. Raij, A.R.Seloki and K. Shirkool. 2014. Assessment of broad sense heritability and genetic advance in safflower. Int. J. of Biosciences. 4(8): 131-135.

Baydar, H. and O.Y. Gökmen. 2003. Hybrid seed production in safflower (Carthamus tinctorius L.) following the induction of male sterility by gibberellic acid. Plant Breed. 122:459461.

Bhatt, G.M. 1973. Significance of path coefficient analysis in determining the nature of character association. Euphytica. 22: $338-343$.

Behnam, T., A.Said, , S. Mohamadreza, B. B Alireza and Gafari, G. 2011. Path analysis of seed and oil yield in safflower (Carthamus tinctorius L.).International Journal of Agriculture and Crop Sciences. P.3-4.

Bidgoli, A.M., G.A. Akbari, M.J.Mirhadi, E.Zand and S. Soufizadeh. 2006. Path analysis of the relationships between seed yield and some morphological and phenological traits in safflower (Carthamus tinctorius L.). Euphytica. 148(3): 261268.

Camas, N., A.K. Ayan and C. Cirak 2005. Relationships between seed yield and some characters of safflower (Carthamus tinctorius L.) cultivars grown in the middle black sea conditions. VI th. International Safflower Conference. 06-10 June 2005, Istanbul.

Chaudhary, S.K. 1990. Path analysis for seed yield in safflower (Carthamus tinctorius L.) in acid soil under mid altitude conditions. International journal of tropical agriculture. 8(2):129-132.

Cosge, B. and D. Kaya. 2008. Performance of some safflower (Carthamus tinctorius L.) varieties sown in late-autumn and late-spring. SDU The Journal of Natural and Applied Sciences. 12(1): 13-18.

Dajue, L.and P. Griffee. 2001. International safflower trials in China, India and Thailand. Sesame and Safflower Newsletter No.16.

Elfadl, E., C. Reinbrecht and W. Claupein. 2010. Evaluation of phenotypic variation in a worldwide germplasm collection of safflower (Carthamus tinctorius L.) grown under organic farming conditions in Germany. Genetic resources and crop evolution. 57(2): 155-170.

Eren, K., D.Başalma, S.Uranbey and C.Er. 2005. Effect of growing in winter and spring on yield, yield components and quality of some safflower (Carthamus tinctorius L.) cultivars in Ankara. VI th. International Safflower Conference, 06-10 June 2005, İstanbul. 
Eslam, B., H. Monirifar and M. Ghassemi. 2010. Evaluation of late season drought effect on seed and oil yields in spring safflower genotypes. Turkish Journal of Agriculture and Forestry 34 (5), 373-380.

Golkar, P., A. Arzani and A.M. Rezaei. 2011. Determining relationships among seed yield, yield components and morpho-phenological traits using multivariate analyses in safflower (Carthamus tinctorious L.). Annals of Biological Research, 2(3): 162-69.

Golparvar, A. R. 2011. Assessment of relationship between seed and oil yield with agronomic traits in spring safflower cultivars under drought stress condition. J. Res. Agric. Sci. 7(2): 109-113.

Hussain,T., M.A.Tariq, I.Ahmad, M.Saghir, M.Batool, M.Safdar and M.Tariq. 2014. Characters association analysis in Safflower (Carthamus tinctorius L.). Journal of Biology, Agriculture and Healthcare. 4(6): 63-65.

Karimi, M., A.R. Golparvar and M.Shams. 2013. Multivariate regression and path coefficient analysis of seed and oil yield in spring safflower (Carthamus tinctorius L.) cultivars. App. Sci. Report. 4 (1): 184-186

Kizil, S., Ö.Çakmak, S. Kirici and M. Inan.2008. A comprehensive study on safflower (Carthamus tinctorius L.) in semi-arid conditions. Biotechnology \& Biotechnological Equipment. 22(4): 947-953.

Koutroubas, S. D., K. Papakosta and A. Doitsinis. 2004. Cultivar and a seasonal effect on the contribution of pre-anthesis assimilates to safflower yield, Field Crops Research. 90: 263-274.

Kolsarıc1, Ö., Ş. Aytekin, N.Vurdu, B. Gönenç. 1993. Distribution of yield components of winter rapeseed (Brassica napus ssp. oleifera L.) cultivars of foreign origin. BS. Thesis. Ankara University. Dep.of Field Crops, Ankara, $19 \mathrm{p}$.

La Fuenta, R.A.B. 1969. Preliminary Result on the Behavior of Safflower at the Estaction Experimental Agropecuaria Rafaela. Field Crop Abstracts. 22(3): 2167

Maas, E.V. 1986. Salt tolerance of plants. Applied Agricultural Research. 1: 12-26

Mündel, H.H., R.J.Morrison, R.E. Blackshaw and B.Roth (eds). 1992. Safflower Production on the Canadian Prairies. Agric. Can. Res. Station, Lethbridge/Alberta Saffl.Growers Assoc., with funding by Farming for the Future Project No. 87-0016, Alberta.35 p.

Nabloussi, A. E., M. Fechtali, S. Lyagoubi, S.E. Knights and T.D. Potter. 2008. Agronomic and technological evaluation of a world safflower collection in Moroccan conditions. In Safflower: unexploited potential and world adaptability. 7th International Safflower Conference, Wagga Wagga, New South Wales, Australia, 3-6 November, 2008: Agri-MC Marketing and Communication. 1-6.

Omidi, A. H., H. Khazaei, P.Monneveux and F. Stoddard (2012). Effect of cultivar and water regime on yield and yield components in safflower (Carthamus tinctorius L.). Turkish Journal of Field Crops. 17(1): 10-15.

Öztürk, Ö. 1994. Investigation on yield and yield components of some safflower cultivars under Konya ecological conditions, MS Thesis, Selcuk University, Grad. School of Nat. Sc. Dep. of Agronomy. $69 \mathrm{p}$.

Pascual-Villalobos, M.J. and N. Alburquerque.1995. Genetic variation of a safflower germplasm collection grown as a winter crop in southern Spain. Euphytica. 92(3): 327-332.

Patil, B.R., S.G. Deshmukh and M.P. Deshmukh. 1990. Studies on correlation and path analysis in safflower. Annals of plant physiology, 4(1): 86-91.

Polat, T. 2007. Effect of different row spacings and nitrogen rates on the yield and yield components of safflower (Carthamus tinctorius L.). PhD Thesis, Atatürk University, Grad. School of Nat. Sc. Dep. of Agronomy, Erzurum.

Sergek, Y. 2001. Determination of Suitable Sowing Time, Variety and Row Distance in Safflower (Carthamus tinctorius L.). MS Thesis, Ankara University, Grad. School of Nat. Sc. Dep. of Agronomy. 73p.

Singh, V. and N. Nimbkar. 2007. Safflower (Carthamus tinctorius L.), in: R.J. Singh (Ed.), Genetic Resources, Chromosome Engineering, Crop Improvement, Oil Seed Crops. vol. 4, New York, CRC press.

Topal, M., E. Ozturk and T. Polat. 2010. Path analysis of seed yield components using different correlation coefficients in safflower (Carthamus tinctorius L.). J. Anim. Plant Sci. 20(4): 220-224.

Tabrizi, A.H.O. 2000. Correlation between traits and path analysis for grain and oil yield in spring safflower. Sesame and Safflower Newsletter (15):78-82. 